\title{
Wykładniki emocji w blogach ojcowskich (przyczynek do lingwistyczno-kulturowych badań nad współczesnym obrazem mężczyzny)
}

ABSTRact: Suska Dorota, Wyktadniki emocji w blogach ojcowskich (przyczynek do lingwistyczno-kulturowych badań nad wspótczesnym obrazem mężczyzny) (Exponents of Emotions in Father's Blogs [a Contribution to Linguistic and Cultural Research on the Modern Image of a Man]). "Poznańskie Studia Slawistyczne" 9. Poznań 2015. Publishing House of the Poznań Society for the Advancement of the Arts and Sciences, pp. 109-121. ISSN 2084-3011.

The aim of the presented analysis is to show the exponents of excitement in the online genre - father's blogs. Men's parenting blogs reflect changes in the field of parenting, where father begins to appear - as an active and participating. This role goes beyond the stereotype of the male and the previous experience of fathers - both media and private. Therefore, the paternal narrative in blogs is for linguists valuable research material, that shows, among others, different aspects of male emotionality and ways to verbalize it. The emotional component of father's image is created by means expressing feelings (not naming them), polyfunctional, used in unusual combinations and contexts.

KeYwords: cultural linguistics; gender stereotype; stereotype of the male; emotions; father's blogs; exponents of male emotions

Problem ekspresywności i emotywności języka był wielokrotnie opisywany w polskiej literaturze lingwistycznej (cf.: Grabias 1981; Nowakowska-Kempna, Dąbrowska, Anusiewicz 2000; Wojtczuk, Wierzbicka 2004; Michalewski 2006). W niniejszym artykule sytuuję go na tle przemian współczesnej kultury, które pozostawiają ślad na wzorcach zachowań jednostkowych i grupowych, także tych dotyczących tożsamości płci. Celem analizy jest ukazanie wykładników emocji w blogach ojcowskich (na przykładzie blogu Peace of milk1 ). Próba dookreślenia językowego

${ }^{1}<$ http://tatatomama.blogspot.com>; przytaczane dalej przykłady podaję w oryginalnym zapisie (z datą wpisu). 
sposobu wyrażania uczuć przez mężczyzn wydaje się zasadna, ponieważ powiązanie emocji z płcią dotyka szerszego zagadnienia reinterpretacji ról społecznych przypisywanych stereotypowo mężczyznom i kobietom, co z kolei pociąga za sobą wielowymiarowe przemiany współczesnej polszczyzny.

Płeć - wzory, obrazy, konwencje językowe - znajduje się w obszarze zainteresowań lingwistyki kulturowej (cf. np.: Anusiewicz, Handke 1994; Długosz 2000: 121-131; Karwatowska, Szpyra-Kozłowska 2005). Kognitywny komponent stereotypów ${ }^{2}$ płci obejmuje: cechy osobowości - kobiece ciepło, ekspresywność versus męska racjonalność, koncentracja; role rozumiane jako społecznie i kulturowo zdefiniowane oczekiwania dotyczące zachowań w określonych sytuacjach społecznych oraz rodzaje aktywności, w których mężczyzna jest głową rodziny, wykazuje inicjatywę, przyjmuje na siebie zobowiązania finansowe, a kobieta opiekuje się dziećmi i dba o dom. Świat mężczyzn jest zbudowany wokół statusu wynikającego z osiągnięć, sprawowanej władzy, pracy zawodowej, świat kobiet natomiast - wokół domowego ogniska i macierzyństwa. Męski styl wypowiedzi nie odznacza się wieloma specyficznymi cechami (neutralne środki polszczyzny ogólnej o funkcji komunikatywnej, wulgaryzmy) (Handke 1994: 19-20), styl kobiecy - przeciwnie, posiada szereg cech swoistych, z wyróżniającą się ekspresywnością (na poziomie środków ekspresji oraz stosunku do rzeczywistości). Cechy te korespondują ze stereotypem matki, na który składają się m.in.: postawa emocjonalna (czułość, serdeczność), uczucia (silna więź z dzieckiem, miłość do niego) i predyspozycje psychiczne (uczuciowość, ciepło, wyrozumiałość) (Bartmiński 1998: 73-74). Stereotyp ojca nie jest doprecyzowany, pozostaje w tle stereotypu mężczyzny, który roli rodzicielskiej nie traktuje pierwszoplanowo.

Również media rodzajowe - zarówno te powstałe po 1989, jak i wcześniejsze - znacznie łatwiej definiują i opisują różne wzory kobiecości i macierzyństwa, dostosowując do nich bogatą ofertę formatów medialnych (Lisowska-Magdziarz 2008: 291-302; Suska 2008: 415-427). Wyrazisty pozostaje także język współczesnej prasy kobiecej (pomijając szczegółowe różnice warunkowane cechami grupy docelowej), który „odzwierciedla społeczną konstrukcję «prawdziwej kobiety»: emocjonalnej, ciepłej,

\footnotetext{
${ }^{2}$ Rozumienie stereotypu przyjmuję za: Witosz 2003: 212.
} 
kompromisowej, nastawionej na komunikację osobistą, skupionej na życiu prywatnym, zainteresowanej szczegółami, o niskich natomiast zdolnościach analityczno-syntetycznych" (Lisowska-Magdziarz 2008: 302). Odbiciem tej konstrukcji jest zespół środków pozwalających osiągać prostotę wypowiedzi, stylistyczną lekkość oraz emocjonalność, a w sposobie opisu świata pozostawać w granicach społecznego, estetycznego i poznawczego komfortu czytelniczki kobiecej. Odmienna sytuacja dotyczy mediów przeznaczonych dla mężczyzn, które w okresie PRL-u prawie nie istniały, bo nie istniała potrzeba definiowania męskiej tożsamości - była ona oczywista, podobnie jak dziedziny ich aktywności. Po 1989 roku pojawiły się, wzorowane na zachodnich, męskie media rodzajowe, utrwalające model mężczyzny hegemonicznego, patriarchalnego, odwołujące się do stereotypowych ról i zainteresowań męskich (erotyka, rozrywka, hobby) lub takie, które umacniały status mężczyzny (pisma biznesowe, publicystyka, magazyny). Obecny w nich język skierowany do mężczyzn cechuje żartobliwe zabarwienie, ironia i dwuznaczność (w różnych proporcjach). Dokonujące się w ostatnich dekadach redefiniowanie męskości nie wpłynęło znacząco na treść mediów rodzajowych adresowanych do tej grupy i zmianę ich języka (Lisowska-Magdziarz 2008: 302); co ważne, nadal brakuje formatów medialnych, które pokazywałyby wzory ojcostwa, przybliżały doświadczenia ojców uczestniczących w wychowaniu dziecka (np. wykorzystujących ,urlop tacierzyński”) i kierowały do nich choćby ofertę poradnikową.

Zmiany w społecznym postrzeganiu i wartościowaniu męskości najpełniej odzwierciedla blogosfera. Do niedawna blogi pisały głównie kobiety (Boniecka 2009: 96); obecnie mężczyźni coraz częściej stają się autorami blogów prywatnych (a nie tylko publicystyki blogowej czy blogów politycznych), budując w nich rodzajowy autostereotyp. Męska blogosfera potwierdza otwarcie na nowe, ,pozastereotypowe” obszary: dominują bowiem ilościowo blogi modowe, ojcowskie, w dalszej kolejności lifestylowe ${ }^{3}$.

Blogi ojcowskie są nowym zjawiskiem w tzw. blogosferze parentingowej (rodzicielskiej), dotychczas zawłaszczonej przez kobiety i ich wizję rodzicielstwa, która na ogół umacnia stereotyp matki, a obowiązująca w nich ,poprawność polityczna” sprawia, że są dość powtarzalne w treści

\footnotetext{
${ }^{3}$ http://kielban.pl/pierwszy-przeglad-meskich-blogow/, sierpień 2014.
} 
i formie stylistyczno-językowej ${ }^{4}$. Męskie blogi dokumentują natomiast „reorganizację” sfery rodzicielskiej in statu nascendi, dlatego też obecna w nich narracja „tacierzyńska” stanowi dla językoznawcy cenny materiał badawczy, ukazujący m.in. różne oblicza ojcowskiej emocjonalności i sposoby jej werbalizacji.

W lingwistyce przyjmuje się, że emocje to typ ekspresji, polegającej na uzewnętrznianiu uczuć (Grabias 1994: 256). Emocje łączą się z oceną rzeczywistości dokonywaną przez nadawcę (pozytywną lub negatywną) i mogą się uzewnętrzniać trojako: w sposób nieuświadomiony, w komunikacji ustnej (w barwie głosu, tempie mówienia, intonacji, mimice) - przejawianie się emocji; implicytnie, gdy emocja wpisana jest w znaczenie wypowiedzi i komunikowana - wyrażanie stanów emocjonalnych; eksplicytnie, za pomocą predykatów nazywających uczucia - nazywanie emocji (Grabias 1981: 26 i n.). Emocje można zatem w języku wyrażać i opisywać, przy czym opisujemy emocje własne i/lub cudze, wyrażamy - tylko własne (Laskowska 2004: 99).

Analizowany w dalszej części blog Peace of milk-egzemplifikujący propozycję lingwistycznego odczytania ojcowskich emocji w wybranym gatunku internetowym - ze względu na charakter można by nazwać identyfikująco-poradnikowym. Autor kreuje w nim (a ściślej - uzewnętrznia) nowy obraz ojca i rodzicielstwa męskiego, dając jednocześnie wskazówki, jak funkcjonować w nieprzyjaznej dla „tacierzyństwa” rzeczywistości (zarówno w wymiarze społecznym, jak i tym całkiem codziennym).

Aktywizowaniu emocji w blogach ojcowskich sprzyja pierwszoosobowa relacja, opisywanie sytuacji z perspektywy uczestnika wyrażającego własny punkt widzenia, subiektywne oceny. Dla właściwego odczytania intencji wypowiedzi zawierającej wykładniki emocji zasadnicze znaczenie ma informacja o standardowości/niestandardowości warunków jej użycia, której dostarcza kontekst pragmatyczny oraz wiedza o charakterze układu interakcyjnego między nadawcą a odbiorcą (Szumska 2000: 201-202). Kontekst taki nakreśla emocjonalny wpis inicjujący czy zapowiadający blog:

${ }^{4}<$ http://www.kominek.in/2013/07/blogi-parentingowe-jest-w-nich-wszystko-conajgorsze-i-najlepsze-w-blogosferze $>$; $\quad<$ http://potworywozkowe.pl/2014/01/definicja-blogow-parentingowych.html>, sierpień 2014. 
Witajcie! (...) Na tym blogu nie zamierzam nikomu tłumaczyć jak się robi dzieci. (...) Względnie prostą sprawą wydaje się być również ciąża i poród. Tak, tak... już słyszę te przekleństwa matek w moim kierunku i teksty ,żebym sam sobie urodził”, ale powiedzcie sami, czym jest 9 miesięcy ciąży i kilka godzin porodu wobec kilkunastu lat wychowywania swojego dziecka? (...) Ano nadarzyła się ku temu wyjątkowa okazja, czyli koniec urlopu macierzyńskiego mamy :). I wraca do pracy. (...) I o tym będzie właśnie ten blog. O tym jak tata opiekuje się dzieckiem od jego 6-go miesiąca życia. Z góry uprzedzam, że nie będzie to blog pitu-pitu jak to fajnie, ale subiektywne uczciwe postawienie sprawy, więc wszystkich wrażliwych na sarkazm i przekleństwa serdecznie zapraszam na inny blog. Resztę witam serdecznie! (12.06.2013).

Autor blogu eksponuje funkcję fatyczną, mającą na celu imitowanie dialogowości, a przede wszystkim spontaniczności typowej dla kontaktów interpersonalnych, co decyduje o sposobie uzewnętrzniania emocji. Rzadko są one w blogu opisywane, a nazywaniu uczuć (funkcja przedstawieniowa) towarzyszy również wyrażanie emocji (funkcja ekspresywna); cechy wypowiedzi odzwierciedlają bowiem stan psychiczny nadawcy oraz silne uczucia, np.:

[tytuł] Czasami wszystko mnie wku...a (post nie dla delikatnych)

Generalnie jestem dosyć cierpliwym człowiekiem. Raczej ciężko wyprowadzić mnie z równowagi i rzadko się irytuję. Jednak od pewnego czasu obserwuję pewien wyjątek. Kiedy dziecko zasypia nagle zaczynają mnie wkurzać przeróżne odgłosy, ludzie, inne dzieci i wszystko dookoła co wywołuje dźwięk. Ten wpis traktuję jako terapię gniewu, gdyż mam wrażenie, że ciśnienie skacze mi czasami zupełnie niepotrzebnie. (...) Plaża to pole minowe jeśli chodzi o dziecko, więc póki była na nogach trzeba było jej non-stop pilnować. Jeśli już udało się jej zasnąć, to bardzo chciałem, aby ta chwila trwała jak najdłużej. Mogłem wtedy położyć się na słońcu, poczytać, poopalać etc. Ale gdy tylko się kładłem, to...nasłuchiwałem. I powoli rósł we mnie gniew. To jakiś dzieciak darł się stojąc o pół metra od mamy (...). To znów jakaś horda biega wokół mojego koca piszcząc bez powodu. (....) No i takich sytuacji jest całe mnóstwo. Jak sobie z tym poradzić? Nie wiem. Jakoś nie potrafię wyluzować (...) (23.09.2013).

Nazywanie emocji odbywa się także nie wprost - poprzez ich omówienie, wzmacniające w określonym kontekście wyrazistość negatywnych emocji, np.:

Siedzimy sobie przy stole, na końcu siedzi mała w foteliku. Stolik przed nami siada małżeństwo z ok 1,5 rocznym synkiem. Płacze dzieciak wniebogłosy, ale uspokaja się na widok Mai i coś tam do niej mówi tajemniczymi sylabami. Maja odpowiada swoimi sylabami i jest spoko. Nagle chłopiec mówi lala, lala. Nadal jest spoko. Po czym tata chłopca - Tak, tam siedzi lala. Tam jest lala. - i dalej sączy sobie piwo z sokiem. Chyba 
nie muszę pisać co sobie pomyślałem o kolesiu sączącym małe piwo z sokiem zwracającym się do mojej księżniczki per lala. Odpowiedziałem możliwie najgrzeczniej jak przyszło mi w tym momencie do głowy - Popatrz Maju, ten chłopiec z tatą myślą, że jesteś zabawką (...) (18.08.2013).

Sygnalizowana wyżej perspektywa kognitywna analizowanego blogu wskazuje, że dominują w nim emocje wartościowane ujemnie. Należy zaznaczyć, że swoista ascetyczność zauważalna jest też w stosowaniu typowych, melioratywnych elementów stylu familijnego: zdrobnień czy hipokorystyków. Najlepszym przykładem są określenia odnoszące się do córki, pozbawione standardowo wyrażanej czułostkowości. Gdy mowa o innych dzieciach, pojawiają się nazwy z pozytywnym komponentem emocjonalnym, ale tylko pojedyncze bazują na formantach systemowo lub kontekstowo melioratywnych:

Mam jednak wrażenie, że Majka wykazuje nieco mniejszy entuzjazm wynikający $\mathrm{z}$ tego rytuału (12.02.2014).

Tuż po narodzinach naszej córki zamieniliśmy naszego wysokiej klasy Opla Astrę na wysokiej klasy połączenie taczki z autobusem w postaci Opla Combo (...). Moje podróżowanie z dzieckiem i wózkiem wygląda bowiem tak (...) (29.01.2014).

Mam wystarczająco czasu na zabawy z małą, której poświęcam każdą chwilę (16.10.2013).

Stolik przed nami siada małżeństwo z ok 1,5 rocznym synkiem (18.08.2013).

A Wy robicie coś ciekawego ze swoimi maluchami czy tylko pieluchy, sprzątanie i gotowanie? (06.08.2013).

W każdym razie jest cała masa osób, która przypisuje swoim bobasom nadzwyczajne zdolności. (09.07.2013).

To jakiś dzieciak darł się stojąc o pół metra od mamy (...) (23.09.2013).

Wiedzą o tym wszyscy Ci, którzy zapełniają żołądki swoich pociech frytkami (...) można upiec placki na zaś lub zmodyfikować przepis tak, aby znalazły się w nim tylko te składniki, które uwielbiają Wasze brzdące (25.02.2014).

Wykładnikami ojcowskiej miłości stają się natomiast oryginalne zestawienia neologiczne, okazjonalne metafory przywoływane wtedy, gdy opisywana jest rzeczywistość budząca skrajnie negatywne emocje. Zamierzony kontrast wzmacnia emocjonalny wydźwięk stosowanych środków, np.:

Jedyne co mogę zweryfikować, to wychowanie i opiekę nad fabrycznie nowym człowiekiem, którego należy nauczyć wszystkiego, co wiąże się z tym wielkim kolorowym i nie zawsze usłanym różami światem (12.06.2013).

Postanowiliśmy, że z naszym małym Skarbem nie będzie siedziała żadna obca baba (12.06.2013). 
Problem w tym, że trzymając na rękach te moje dwa śliczne niebieskie oczka, wcale nie mam ochoty na podryw (19.06.2013).

Przyjęcie autorskiej strategii podkreślającej nieoficjalność łączy się z potocznością: w ujęciu kulturowym (rozumianym jako sposób kategoryzowania rzeczywistości, typ racjonalności) oraz komunikacyjno-stylistycznym. Stąd tak dużą grupę leksykalnych wykładników emotywności stanowią ekspresywizmy - od potocyzmów o różnym stopniu nacechowania emocjonalnego, aż po wulgaryzmy.

Kolokwializmy (w tym połączenia neologiczne) są eksponentami emocjonalnego zaangażowania nadawcy, zwłaszcza we wpisach o charakterze poradnikowym, na tle neutralnych tytułów i otoczenia, jakim jest przekaz nastawiony na komunikatywność, np.:

[tytuł] Co dawać dziecku do jedzenia na spacerze

Zaletą moich placków jest to, że można podać je w rękę i stanowią dużo większą wartość odżywczą niż wspomniane chrupki. Dodatkowo dziecko nie uświni się za bardzo.

(...) Zatem odwalę tutaj kulinarną gejozę i w tym poście zajmiemy się pieczeniem placków (25.02.2014).

[tytuł] Jak zrobić ciekawą, kreatywną i rozwijając zabawkę dla dziecka

Chciałbym być nieco bardziej kreatywnym tatą, ale od dłuższego czasu nie pijam wódki, ani nie stosuję innych specyfików stąd generalnie w tym temacie lekka dupa (11.11.2013).

Potocyzmy jako wykładniki emocji, osadzone w szerszym kontekście, mogą być sygnałem konotacji dodatnio lub ujemnie wartościowanych. Generalnie, jak w powyższych przykładach, są one pozytywne, bywają jednak używane także dla uzewnętrznienia emocji negatywnych - złości, lekceważenia, np.:

Po pierwsze nie tracę kontaktu z rzeczywistością. Nie spędzam każdej wolnej chwili na forach internetowych naparzając się z masą zapyziałych matek dyskutujących na temat karmienia w miejscach publicznych, poruszających wciągające tematy cycek czy butelka, albo tępo gapiąc się na Kawę czy herbatę lub Dzień dobry TVN (16.10.2013).

Liczną grupę wykładników emotywności bezpośredniej (polifunkcyjnych - ze względu na wyraźne obciążenie stylistyczne i ekspresywne) stanowią wulgaryzmy. Standardowo są one znakiem silnych, negatywnych przeżyć osoby, która się nimi posługuje w danej wypowiedzi lub/i 
- używane nieświadomie - przejawem niskich kompetencji językowych nadawcy, nieumiejętności wyrażania emocji innymi środkami. Intencjonalną obecność wulgaryzmów w omawianym blogu uzasadnia nawiązanie do rodzajowego wzorca wypowiedzi: są jednym z głównych wyznaczników męskiej emocjonalności i jako takie ewokują na płaszczyźnie językowej męski stereotyp. Autor blogu stara się tak sprofilować językowo narrację ojcowską, by pokazać, że bycie aktywnym rodzicem nie zaciera obrazu „prawdziwego" mężczyzny, który wyraża emocje (nawet pozytywne) „po męsku” - i odwrotnie: ,prawdziwy” mężczyzna nie musi być złym ojcem. Wyrazistym przykładem tak organizowanej emotywności wypowiedzi jest wpis dotyczący narodzin córki i decyzji o „tacierzyństwie”: radość, duma, zachwyt kumuluje się w takich środkach jak wulgaryzmy, operatory ekspresywne, które wraz z emocjonalną składnią (repetycje, wykrzyknienie) i poetyckim obrazowaniem hiperbolizują ojcowskie odczucia:

Wszystko zaczęło się w zasadzie od przecięcia pępowiny. To zabieg, którego wcale nie miałem zamiaru wykonywać i nie był on punktem mojego honoru dopóki położna po porodzie nie powiedziała uprzejmie - proszę pan przetnie. Oczywistą reakcją było: Ja nie przetnę? Ja qwa nie przetnę? I przeciąłem. (...) I wtedy, na tej wadze, pierwszy raz otworzyła na chwilę oczy. I zobaczyłem, że te oczy są dokładnie takie jak moje. Identyczne! I to był ten moment - ostateczne stwierdzenie, że to są moje oczy już na zawsze. Taki moment daje wiarę w to, że jest się gotowym absolutnie na wszystko, aby tylko zasłużyć choć na krótkie spojrzenie. Dlatego kiedy moja żona czuła się na siłach, aby wrócić do pracy, bez wahania podjąłem się opieki nad córką (...) (16.10.2013).

Wulgaryzmy (eufemizowane graficznie, niemniej łatwe do odtworzenia), wraz z potocyzmami z niskiego rejestru, stają się nie tylko wyrazem indywidualnych reakcji emocjonalnych autora, ale też manifestacją myślenia grupowego, np.:

Pierwsze pytanie, które zadają koledzy kiedy dowiadują się, że wychowujesz dziecko? Gdyby mnie ktoś zapytał, to bym odpowiedział, że jest to coś koło „Poj...ało cię?” albo „Och...leś?”. Tymczasem okazuje się, że u większości populacji męskiej kłębi się gdzieś w głowie taka opinia, że laski lecą na kolesi z dziećmi i nagle spotykają kogoś, kto może wypowiedzieć się w tym temacie. (...) Prawda jest taka, że dziecko jest zajebistym wabikiem kobiet. (...) Mam tylko jedną wskazówkę. Dziecko musi być na rękach (...). Koleś z wózkiem, i to jeszcze z parasolką wygląda co najmniej pedalsko (19.06.2013). 
Wulgaryzmy pełnią ponadto funkcję leksykalnych sygnałów emocji negatywnych (zniecierpliwienie, złość), świadcząc o ich intensywności, która skłania nadawcę do przekraczania granicy językowej stosowności. Autor blogu ma świadomość tej granicy, wulgaryzmy są bowiem częścią jego narracji o emocjach i zderzają się z formą przytaczanych dialogów, w których te same emocje wyrażane są za pomocą odmiennych środków:

Plaża to pole minowe jeśli chodzi o dziecko, więc póki była na nogach trzeba było jej non-stop pilnować. Jeśli już udało się jej zasnąć, to bardzo chciałem, aby ta chwila trwała jak najdłużej. (...) Ale szalę goryczy przebrała rodzinka z czwórką dzieci, której przewodniczył nader bystry tata, który teatralnym szeptem powiedział:

- Chodźcie tu, będziemy lepiej osłonięci od wiatru (...).

Cała plaża wpizdu pusta jak okiem sięgnąć, a ten kutas postanowił rozbić się właśnie obok mojej śpiącej królewny. I napierdala kamieniem w te patyczki...

- Błagam pana, niech pan troszkę ciszej stuka, bo mi właśnie dziecko zasnęło i mam chwilę dla siebie - mówię.

- A jasne przepraszam - odpowiada.

No i ch..j mi po jego uprzejmości kiedy już mi się dziecko obudziło (23.09.2013).

Emocjonalne wykładniki zaangażowania autora blogu w walkę o uznanie męskiego rodzicielstwa reprezentują, poza już wymienianymi środkami, zaskakujące odniesienia, będące źródłem emotywnych konotacji o ujemnym wartościowaniu:

W życiu nie zwracałem na to uwagi, ale z całą pewnością mogę stwierdzić, że dyskryminacja ojców jest sprawą, która wymaga natychmiastowej interwencji rządu, cichych marszów i kto wie może nawet happeningu z muzyką techno i platformami. Gejów, żydów, czarnych, żóltych czy czerwonych na pewno nie spotyka tyle utrudnień w życiu codziennym (...) (27.06.2013).

Wyraźnie określona postawa autora wobec aktywnego, uczestniczącego ojcostwa to dla odbiorcy istotna sugestia interpretacyjna, pozwalająca na odczytywanie nie tylko emocjonalnych konotacji, ale też gier konwersacyjnych (Łuc 2010: 9), takich jak ironia czy sarkazm. Wspomniane gry (pozornie łamiące maksymy odniesienia) odwołują się bowiem do wspólnej wiedzy nadawcy i odbiorcy, do wspólnotowości poglądów (którą autor blogu konsekwentnie buduje) i opierają się na interpretowaniu, dookreślaniu, aktualizowaniu znaku emocji środków językowych, umieszczanych w nowym, dość zaskakującym, nietypowym kontekście. Tak implikowanej 
emocjonalności towarzyszy często żartobliwy dystans, który intensyfikuje odczucia autora:

Nie wiem czemu, ale większość niewygodnych sytuacji wiąże się z kiblem. I tak np. kolejna sytuacja, która zdarza się niezwykle często, to małe toalety, do których nie można się zapakować z wózkiem. Tata też człowiek i czasem się musi odlać. I w niektórych przypadkach wygląda to tak, że wchodzę do klopa i sikam do pisuaru z dzieckiem na ramieniu. Nie dość, że to kombinacja alpejska, to na dodatek Majka jest zachwycona faktem chlupania sików o ten pisuar, że zaczyna się wyrywać i chce koniecznie zobaczyć co się tam dzieje. Wyobrażacie sobie jak to wygląda? Sam się czasami śmieję... (27.06.2013)

Ludyczność, połączona z sarkazmem czy ironią, staje się typowym dla narracji ojcowskiej narzędziem wyrażania skrajnych emocji. Męski humor bazuje na wieloznaczności (uruchamiającej nierzadko erotyczne skojarzenia), zaskakującym konkretnością (i dosadnością) obrazowaniu, ekspresywnym słownictwie i frazeologii, emocjonalnych strukturach składniowych, stylistycznych kontrastach, np.:

[deprecjacja nieakceptowanych zachowań: wzburzenie, złość]

W ogóle co to jest za tekst?! Rozmawiam sobie z kolegą o dzieciach, od slowa do słowa, a on nagle wypala dumnie „No mój już stoi”. I nie wiadomo czy pedal czy pedofil... A tak bardziej poważnie, to chodzi mi o przerost ambicji rodziców wobec własnych dzieci (...). W każdym razie jest cała masa osób, która przypisuje swoim bobasom nadzwyczajne zdolności. Zazwyczaj wiążą się z postępami w rozwoju (...). Możecie zatem wciskać kity, że dziecko siedzi w trzecim miesiącu jakimś niedoświadczonym licealistom, którzy i tak mają to w dupie. (...) już apogeum wykonał mój znajomy (pozdrawiam), który właśnie stwierdzil, że ,jego już stoi”. No to mówię „to pokaż”, no i idziemy do łóżeczka, a tam klucha leży i widać, że jeszcze brakuje mu sił do podniesienia własnej ręki, nie mówiąc już o wstawaniu, ale jestem dalej ciekaw jak stoi. Szybki manewr - podnosimy dziecko, ręcznie haczymy rączki o szczebelki łóżka. Dziecko napina nóżki i stoi przez rzeczone 5 sek. No k...wa...chyba zaraz zacznie mówić (09.07.2013).

[przezwyciężenie choroby dziecka: radość, satysfakcja]

Zaczęło się całkiem niewinnie. Katarek. Nie pierwszy i nie ostatni katarek w życiu, więc procedura standardowa - witaminka $\mathbf{C}$, wapno i wysysanie glutów. Nie lubicie wysysania glutów? Powiem Wam, że w pewnym sensie podoba mi się ta procedura. Daje mi dyskretne poczucie satysfakcji. Tym jest ona większa, im glut jest dłuższy. Jak wyciągnę długiego gluta, to czuję satysfakcję porównywalną z pozbyciem się uporczywego kawałka mięsa spomiędzy zębów. Dodatkowo dopinguje mnie myśl o tym, że moja córka będzie mogła oddychać. (...) Mam jednak wrażenie, że Majka wykazuje nieco mniejszy entuzjazm wynikający $\mathrm{z}$ tego rytuału. (...) Znalazłem jed- 
nak na to sposób. Po każdym wyciągniętym glucie biję jej brawo i wiwatuję - Braaawoooo, heeeej! Pomyślałem, że jak działa z robieniem kupy na nocnik, to zadziała i przy glutach. Nie pomyliłem się. Teraz wspólnie oddajemy się pasji opróżniania nosa (...) (12.06.2014).

Na koniec warto podkreślić, że ludyczność pełni funkcję ekspresywną w szerszym znaczeniu i łączy się z perswazją; ukazując siebie jako osobę inteligentną, dowcipną, błyskotliwą, autor wyzwala u odbiorców pozytywne odczucia, dzięki czemu łatwiej akceptują jego poglądy, prezentowane oceny. Oto jeszcze jeden z przykładów realizacji strategii, o której wyżej mowa:

Czytam sobie komentarze pod różnymi pobocznymi publikacjami o moim blogu i trochę to wszystko jest przerażające. (...) przerażający jest wizerunek mężczyzny w społeczeństwie. Absolutnie nie chcę tutaj napadać na komentujące panie (to same panie są), tylko wyciągnąć pewien wniosek i podziękować za walkę ze stereotypami dot. naszej silnej płci. (...) posłużę się cytatami z wypowiedzi internautek (...). Do każdej antytezy postaram się dobrać tezę, z którą owe panie starają się walczyć. Zacznijmy od pierwszego z brzegu: „(...) mąż zajmuje się córą rewelacyjnie:) jest czuły, opiekuńczy (...)”. No i fajnie - myślę - dziewczyna potwierdza fakt, że tatusiowie są dobrymi opiekunami, ale od razu nasunęło mi się pytanie czemu takie potwierdzenie? Z czym trzeba walczyć? Skoro należy napisać, że jest czuły i opiekuńczy, to znaczy, że tezą jest nieczuły barbarzyńca? No chyba tak, bo widzieliście kiedyś wpis, który mówił by, że Moja żona zajmuje się dzieckiem - jest czuła i opiekuńcza? Nie. U kobiet przyjmuje się to jako pewnik. Zatem prawdopodobnie wizerunek mężczyzny zajmującego się dzieckiem można określić zdaniem: Mąż zajmuje się córą ch..owo. Dręczy ją stukając metalową rurką o szczebelki łóżka i zostawia na kilka godzin samą bez jedzenia (...) (05.09.2013).

Redefiniowanie kulturowych i mentalnych skryptów to proces permanentny, wnoszący do współcześnie istniejących (tworzonych) obrazów męskości i męskiego rodzicielstwa coraz to nowe elementy, wyrażane przez semiotyczny język kultury (Fuszara 2008; Bierca 2013: 79-88). Jego znakiem są m.in. jednostki zwerbalizowane, których ukształtowanie - podporządkowane emotywności - uwypukla jeden z istotnych aspektów nowego ojcostwa opiekuńczego (Legomska 2006: 526-529). Dlatego też konieczne wydaje się prowadzenie badań na niewielkich, ale zróżnicowanych próbach badawczych, powtarzanych w odstępach czasowych; taki też cel (cząstkowego opracowania, przyczynku do syntetyzujących ustaleń) uwzględniono przy wyborze materiału źródłowego, który miał stanowić 
przykład określonego gatunku w jego rodzajowej realizacji. Blogi ojcowskie, pisane z perspektywy pierwszoosobowej, uczestniczącej, dają znaczące podstawy do opisu współczesnego obrazu mężczyzny (,takiego, jaki jest") (Bartmiński, Panasiuk 2001: 379-380), w którym nie tylko uwzględnia się rolę rodzica, ale przyznaje się jej wysoką rangę. Wnioski z przeprowadzonych badań - mimo że częściowe, ze względu na zamierzone ograniczenie materiału źródłowego - pozwalają potwierdzić kierunek modelowania tradycyjnego, zbudowanego na racjonalnym myśleniu, stereotypu mężczyzny-ojca. Kierunek ten wyznacza emocjonalność, wyraźnie widoczna $\mathrm{w}$ relacjach $\mathrm{z}$ dzieckiem (dziećmi), ale też stanowiąca ważny składnik tożsamości nowego mężczyzny: „obecnie przyznaje się ojcom (i szerzej: mężczyznom) prawo do wyrażania własnych uczuć, emocji, pragnień" (Legomska 2006: 528).

W wybranym blogu emocjonalny komponent obrazu ojca współtworzą w większości środki wyrażające uczucia pośrednio, polifunkcyjne, używane w niestandardowych połączeniach i kontekstach. Odczytanie wartościowania (ujemnego lub dodatniego) wykładników implikujących i konotujących emotywność umożliwia dookreślona postawa autora, prezentującego siebie jako przedstawiciela wspólnotowego, męskiego „my”.

W zakresie badań nad emotywną funkcją języka przedstawione analizy egzemplifikują efekty oddziaływania kulturowych i pragmatycznych czynników profilujących ekspresję i sposoby wyrażania emocji, wykorzystując inspirujący badawczo (z powodu rodzajowej reprezentatywności) gatunek internetowy.

\section{Literatura}

Anusiewicz J., Handke K. (red.), 1994, Języka a kultura, t. 9, Płeć w języku i kulturze, Wrocław.

Bartmiński J., 1998, Podstawy lingwistycznych badań nad stereotypem - na przykładzie stereotypu ,matki”, w: Język a kultura, t. 12, Stereotyp jako przedmiot lingwistyki. Teoria, metodologia, analizy empiryczne, red. J. Anusiewicz, J. Bartmiński, Wrocław, s. 63-83.

Bartmiński J., Panasiuk J., 2001, Stereotypy językowe, w: Współczesny język polski, red. J. Bartmiński, Lublin, s. 371-394.

Bierca M., 2013, Tacierzyństwo w sieci-analiza nowego trendu i jego socjologiczne implikacje, „InterAlia: Pismo poświęcone studiom queer” nr 8, s. 78-90. 
Boniecka B., 2009, Językowa prezentacja (płci) nadawcy w blogu, w: Komunikowanie (się) w mediach elektronicznych. Język, edukacja, semiotyka, red. M. Filiciak, G. Ptaszek, Warszawa, s. 96-111.

Długosz K., 2000, Językowy obraz kobiety i mężczyzny w polszczyźnie potocznej, „Prace Filologiczne" t. 45, s. 121-131.

Fuszara M. (red.), 2008, Nowi mężczyźni? Zmieniające się modele męskości w Polsce, Warszawa.

Grabias S., 1981, O ekspresywności języka, Lublin.

Grabias S., 1994, Język w zachowaniach społecznych. Lublin.

Handke K., 1994, Język a determinanty płci, w: Języka a kultura, t. 9, Płeć w języku $i$ kulturze, red. J. Anusiewicz, K. Handke, Wrocław, s. 15-29.

Karwatowska M., Szpyra-Kozłowska J., 2005, Lingwistyka płci. Ona i on w języku polskim, Lublin.

Laskowska E., 2004, Emocje $w$ dyskursie parlamentarnym, w: Funkcja emocjonalna jednostek językowych i tekstowych, red. K. Wojtczuk, A. Wierzbicka, Siedlce.

Legomska J., 2006, „Prawdziwy mężczyzna nie uważa, że dziecko to sprawa kobiet”. Modelowanie stereotypu ojca w prasie adresowanej do rodziców, w: Oblicza komunikacji 1. Perspektywy badań nad tekstem, dyskursem i komunikacja, red. I. Kamińska-Szmaj, T. Piekot, M. Zaśko-Zielińska, Kraków, s. 517-535.

Lisowska-Magdziarz M., 2008, Media powszednie: środki komunikowania masowego i szerokie paradygmaty medialne w życiu codziennym Polaków u progu XXI wieku, Kraków.

Łuc I., 2010, Współczesne gry komunikacyjno-językowe, Katowice.

Michalewski K. (red.), 2006, Wyrażanie emocji, Łódź.

Nowakowska-Kempna I., Dąbrowska A., Anusiewicz J. (red.), 2000, Języka a kultura, t. 14, Uczucia w języku i tekście, Wrocław.

Suska D., 2008, Stereotyp ptci we współczesnej prasie kobiecej (lingwistyczno-kulturowe aspekty wartościowania), w: Język - społeczeństwo - wartości, red. E. Laskowska, I. Benenowska, M. Jaracz, Bydgoszcz, s. 415-425.

Szumska D., 2000, O emocjach bez emocji, w: Język a kultura, t. 14, Uczucia w języku i tekście, red. I. Nowakowska-Kempna, A. Dąbrowska, J. Anusiewicz, Wrocław, s. 199-207.

Witosz B., 2003, Przeciw stereotypom - ku stereotypowi? (O ksztaltowaniu postaci $w$ najnowszej prozie polskiej), w: Stereotypy w literaturze (i tuż obok), red. W. Bolecki, G. Gazda, Warszawa, s. 212-228.

Wojtczuk K., Wierzbicka A. (red.), 2004, Funkcja emocjonalna jednostek językowych i tekstowych, Siedlce. 